\title{
Innovation as a mediator between Innovative Culture, Transformational Leadership, Knowledge Management, Learning Orientation, and Performance
}

\author{
Hina Zafar ${ }^{1}$ \\ Khawaja Khalid Mehmood ${ }^{2}$
}

\begin{abstract}
It is believed that for small and medium-sized enterprises (SMEs), innovation is most important to deliver performance. Literature indicates that the most significant antecedents of innovation are learning orientation, transformational leadership, knowledge management, and innovative culture. Further, a research gap exists regarding the mediating effect of innovation for the relationships among these antecedents and SMEs performance in the Pakistan context. The scope of research is limited to SMEs and is novel and significant in this regard that it examines the mediatory role of innovation for the relationships between learning orientation, transformation leadership, knowledge management, innovative culture, and performance for Pakistani SMEs. This research employed quantitative research design and collected primary data from 150 SMEs (including retailers, hotels, restaurants, and boutiques) of Southern Punjab region. Area sampling technique was used wherein areas were selected randomly. Respondents were top managers/owners of SMEs. This research concludes that innovation does play a mediatory role. It contributes and strengthens transformational leadership theory, resource-based theory, theory of the growth of firms, and dynamic capabilities perspective. The study also contributes by providing practical implications and suggestions to the policy makers and managers of SMEs. It suggests that managers must develop an innovative culture to promote innovation and attain high performance. Further, effective knowledge management guarantees innovation and superior performance of the organization. Regarding, learning orientation, it suggests that information must be obtained from and communicated to all the employees for fostering innovation and high performance. Finally, the transformational leadership style must be used by leaders for enhancing the creativity of employees and improving SME performance.
\end{abstract}

JEL Classification: $M 1, M 14, M 59$

Keywords: Innovation, innovative culture, knowledge management, learning orientation, organization performance, Pakistani SMEs, transformational leadership.

\section{INTRODUCTION}

An organization's performance is its ability to attain its goals efficiently and effectively, and if it does so, it could become successful in achieving long term competitive advantage (Ricardo \& Wade, 2001). Tidd (2001) argues that companies could better exploit market opportunities by adopting innovation. Other scholars have majorly concluded that amongst others, innovation has been an important contributory factor for organizations performance in multiple contexts (Gault, 2018; Mehmood, Sonia, \& Umar, 2016; Rajapathirana \& Hui, 2018). For instance, Zahra, Belardino, and Boxx (1988), Damanpour and Evan (1984) have found a

1 \& 2- Institute of Management Sciences, Bahauddin Zakariya University Multan. (khawjakhalid@bzu.edu.pk)

\begin{tabular}{llll}
\hline JISR-MSSE & Volume 17 & Number 1 & January-June 2019 \\
\hline
\end{tabular} 
positive effect of innovation on organization performance in various industries including service-based and administrative organizations. In a more recent study conducted in the context of transitional economy in South-Eastern Europe, Turulja and Bajgoric (2019) suggested that product innovation and process innovation, both positively affected performance of the various type of firms.

Innovation could be determined by certain important strategic factors. For instance, learning orientation is supposed to be concerned with getting a high level of organizational performance through the use of new knowledge for developing new offerings (Hurley \& Hult, 1998). Further, organization culture contains the ability to foster innovation and performance (Hartmann, 2006). Empirical researches have also suggested the positive nature of the association between culture, innovation and company performance (Gallagher, 2008; Miron, Erez, \& Naveh, 2004). Similarly, knowledge management is critical in fostering innovation and enhancing performance (Gloet \& Terziovski, 2004; Parlby \& Taylor, 2000). Also, transformational leadership is supposed to motivate human resources for getting innovative products and achieving better performance (Elkins \& Keller, 2003; Seaver, 2010). Importantly, several scholars have suggested that variables like learning, transformational leadership, knowledge management, and innovation have been significant for stimulating SMEs' growth and development (Bessant \& Tidd, 2007; Hogen \& Coote, 2013; Nunes, Annansingh, \& Eaglestone, 2006; Tajasom, Hung, Nikbin, \& Hyun, 2015).

\section{Problem statement \& research significance}

Hence, in this area, the critical literature review indicates that although innovation has been studied in the past by numerous scholars but its antecedents and performance consequences are still knotty questions. Especially, innovation's intervening nature of effect between innovative culture, knowledge management, transformational leadership, learning orientation and performance of SMEs has not been studied earlier in one research design which is a significant research gap. Specifically, the information about how and to what extent SMEs need to focus on building an innovative culture, fostering learning, encouraging transformation leadership, and facilitating knowledge management processes for addressing innovation and boosting performance is lacking. Furthermore, this kind of investigation for Pakistani SMEs working in diverse sectors is also deficient which further signifies the research gap and the need for this study as it highlights the absence of significant information in this regard. The study takes into account the SME sector of Pakistan because it is quite significant in terms of its contribution to the country's growth and development. The findings of this study are supposed to contribute to resource-based theory, the theory of the growth of firms, dynamic capabilities perspective, and transformational leadership theory; as well as the findings, guide SMEs about how they could be more innovative and competitive in the world place.

\section{LITERATURE REVIEW}

\section{Innovative culture, innovation, and performance}

It is suggested that an innovative culture fosters the production of new products and services and helps in adopting innovative ideas (Skilbeck, 2017). Key features of innovative culture are adaptability among employees, entrepreneurship, risk-taking, and creativity (Carrillat, Jaramillo, \& Locander, 2004). Martins and Terblanche (2003) suggested that innovative culture was one of the critical success factors for achieving superior organizational

150 January-June 2019 Volume $17 \quad$ Number 12 JISR-MSSE 
performance. Innovative culture enhances creativity, and freedom and helps employees in achieving a superior level of performance (McLean, 2005). Further, innovation contains the ability to lead to high levels of firm performance (Abouzeedan, 2011). Although certain past scholars disaffirmed this relation (Tidd, Bessant, \& Pavitt, 2002; Kaufmann \& Tödtling, 2001), others have argued in favor of positive innovation's impact on firm performance (Oncioiu, 2013; Rajapathirana \& Hui, 2018). For instance, Kumarasinghe (2018) reported a positive effect of innovation on the performance of Sri Lankan SMEs. This research argues that an organization could build innovation and attain high performance by well exploiting its intangible resources like innovative culture and knowledge (Amit \& Schoemaker, 1993; Kostis, Kafka, \& Petrakis, 2018) and hence contributes to resource-based view. Hence, the discussion leads to the following hypothesis:

H1: The relationship between innovative culture and organization performance is mediated by innovation.

\section{Transformational leadership, innovation, and performance}

TL is used for motivating human resources by use of intellectual stimulation, charisma, and motivation (Seaver, 2010). Studies have demonstrated that transformational leadership played a significant role in enhancing job satisfaction and SMEs' performance (Ghosh, Liang, Meng, \& Chan, 2001; Hanaysha et al., 2012). Further, transformational leaders play a significant role in creating innovative climate through motivating employees by their charismatic speech (Jung \& Sosik, 2002) and their behavior acts as the driving force behind employee creativity (Bass \& Avolio, 1995). In their study of Iraq's Higher Education Institutions, Al-Husseini \& Elbeltagi (2016) reported that transformational leadership played a significant role in improving product and process innovation in public as well as the private sector. This research builds its hypothesis on the basis of transformational leadership theory (Burns, 1978) as well as linking transformational leadership with creativity and performance (Akbari, Younesi, \& Zohoori, 2017). So, it could be hypothesized that:

H2: Innovation mediates the relationship between transformational leadership and organizational performance.

\section{Knowledge management, innovation, and performance}

Knowledge management concerns interdependent activities and processes such as valuation of knowledge, its creation, distribution, and storage (Gonzalez \& Martins, 2017). Baddi and Sharif (2003) suggest that knowledge management provides easy access to expertise for searching new capabilities and knowledge, thus contributing to a high level of performance. Nunes et al. (2006) research for South Yorkshire SMEs found if knowledge was managed effectively, it could lead to higher innovation and performance. Cavusgil, Calantone, and Zhao (2003) assert that organizations which actively pursue knowledge management are often more efficient in producing innovative products and services and become successful in achieving high performance. In their study of 1139 Taiwanese high-tech companies, Hung, Lien, Fang, and Mclean (2010) suggested that knowledge management was positively related to innovation and TQM performance. So, on the basis of these, it is hypothesized as:

H3: The relationship between knowledge management and organization performance is mediated by innovation.

\begin{tabular}{llll}
\hline JISR-MSSE & Volume 17 & Number 1 & January-June 2019 \\
\hline
\end{tabular}




\section{Learning orientation, innovation, and performance}

It is believed that learning orientation helps in achieving better performance (Baker \& Sinkula, 2009). Learning orientation positively affects innovation and strongly supports new ideas (Kharabsheh, Ensour, \& Bogolybov, 2017) as it challenges old concepts and methods. Many researchers established a positive impact of learning orientation on innovation (Baker \& Sinkula, 1999; Liao, Chang, Hu, \& Yueh, 2012). For instance, the positive effect of learning orientation and innovation on SMEs performance was discovered in the context of Yemen (Jabeen et al., 2013). The present study supports dynamic capability perspective-DCP (Teece, Pisano, \& Shuen, 1997) and suggests that learning orientation leads to better exploitation of knowledge for operating in fast moving competitive forces and environment. Similarly, it strengthens RBV (Amit \& Schoemaker, 1993) as well as Penrose's (1959) theory of the growth of firms as it suggests that a learning-oriented organization could lead to a higher degree of innovation thus leading towards higher performance. Hence, finally, it is hypothesized that:

H4: Innovation mediates the relationship between learning orientation and organization performance.

\section{Conclusion}

Thus, hypotheses $\mathrm{H} 1$ to $\mathrm{H} 4$ are developed to address the central research question of how important factors including learning orientation, transformational leadership, knowledge management, and innovative culture affect innovation and performance of SMEs. It is noteworthy that in spite of the availability of certain past studies on the topic, innovation and performance relationship is still a perplexing and complicated question as evident through certain researches conducted most recently on the topic (see for instance, Kneipp, Gomes, Bichueti, Frizzo, \& Perlin, 2019; Turulja \& Bajgoric, 2019; Wang, 2019). The perspectives and objectives of these researches are different yet they all lend support for complex nature of the phenomena; as well as for studying these relationships for different sectors, in different contexts, and using new perspectives.

Importantly, a recent study of Manzoor et al. (2019) on transformational leadership, performance, and corporate social responsibility in the context of Pakistan's SMEs suggested using mediators in the relationships for better knowledge formation. Another recent study by Waheed, Miao, Waheed, Ahmad, and Majeed (2019) conducted on New HRM practices, innovation, innovative climate, and performance of IT-based companies in Pakistan also suggested conducted further studies in other sectors and collecting more evidence to enrich the understanding on concerned variables. Another study (Hussain, Shah, Rahman, \& Khan, 2018) accomplished for manufacturing based SMEs suggested doing further research on learning orientation, entrepreneurial orientation, and performance for Pakistan based SMEs working in other sectors such as hospitality and food. Hence, it is believed that with the help of its research framework and design, this study pays a genuine contribution towards the understanding of different relationships for Pakistan based SMEs as well as contributes to knowledge up gradation for significant theories.

\section{METHODOLOGY}

Two hundred and fifty SMEs of Southern Punjab region were selected for this study. Most of the SMEs were hotels, restaurants, shoe retailers, and boutiques, etc. Questionnaires were sent 
to managers, owners, senior executives, and supervisors. Area sampling technique was utilized for this research. 250 questionnaires were sent to concerned SMEs and 150 were obtained in return (response rate: 60\%) among which 125 were valid responses. Among 125, 110 were male respondents. The questionnaire was developed using past studies' research instruments. Table 1 shows sources from where items for various constructs were acquired.

Table 1. Sources for Measurement Scale

\begin{tabular}{lcl} 
Variables & No. of Items & Source \\
\hline Innovation & 10 & Calantone, Cavusgil, and Zhao (2002) \\
\hline Organization Performance & 6 & Felício, Couto, and Caiado (2014) \\
\hline Innovative Culture & 5 & Skerlavaj, Song, and Lee (2010) \\
\hline Transformational Leadership & 5 & Podsakoff, Mackenzie, and Bommer (1996) \\
\hline Knowledge Management & 7 & Rasula, Vuksic, and Stemberger (2012) \\
\hline Learning Orientation & 5 & Sheng and Chien (2016). \\
\hline
\end{tabular}

As provided in the table, different studies were referred to selecting the most suitable set of items for different constructs. In addition, the items were adopted from the past studies and they were tested for their reliability and validity as discussed in the analyses.

\section{ANALYSES, RESULTS, AND CONCLUSIONS}

The analyses were conducted using Smart PLS3.0. A measurement model and the structural model were run. The measurement model showed satisfactory results for validity and reliability of scales. For instance, consider Table 2 for factor loadings. All item loadings are greater than 0.70 that indicate convergent validity (Henseler, Ringle, \& Sarstedt, 2012).

Table 2. Factor Loadings

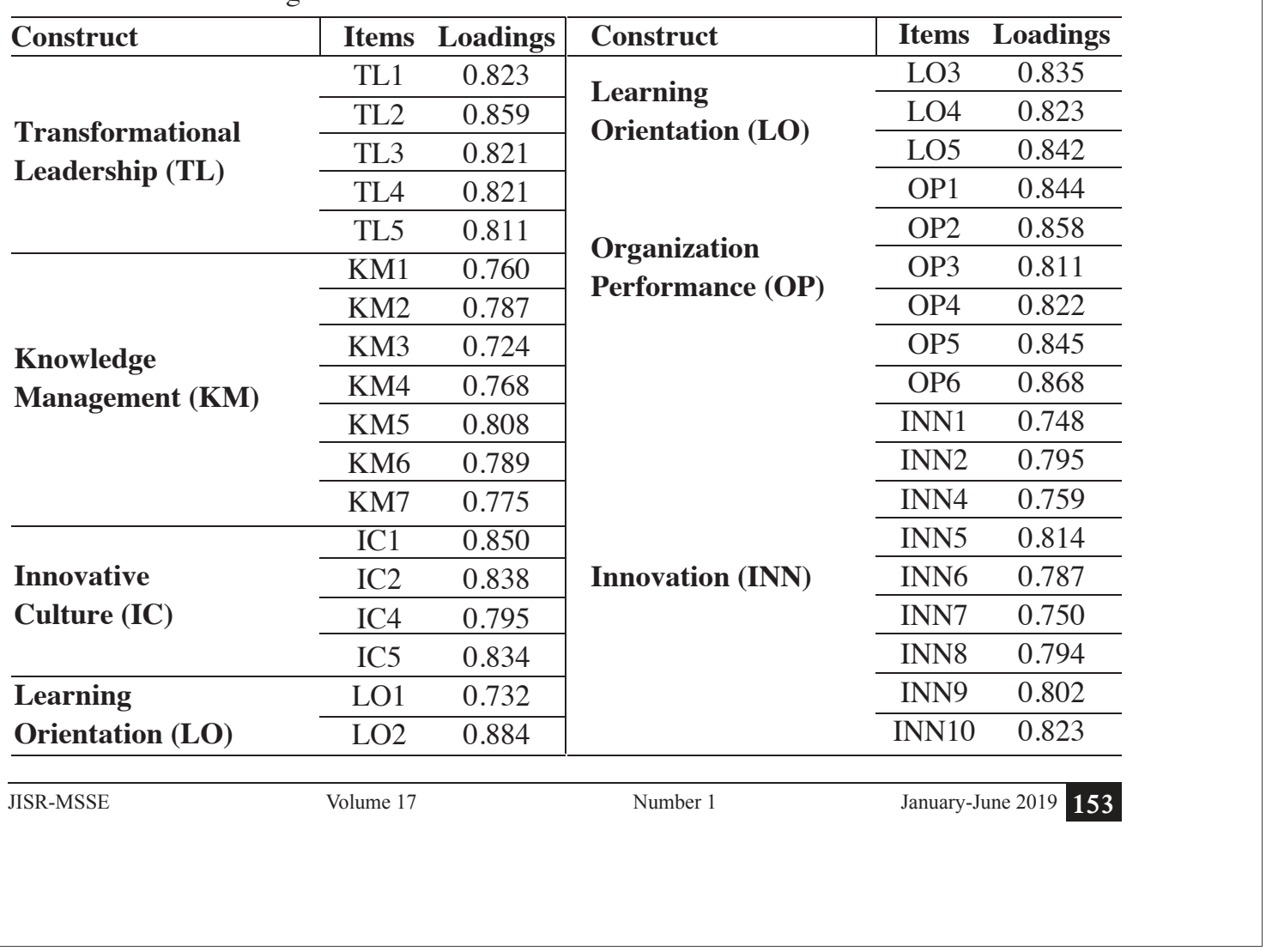


Further, convergent validity was also established as composite reliability (Table 3) was higher than 0.7 (Daskalakis \& Mantas, 2008). Reliability was also ensured because Cronbach's alpha (Table 3) was greater than 0.70 for all constructs (Nunnaly, 1978). For all, Heterotrait-Monotrait ratio was less than 1.00 , so the condition for discriminant validity was also satisfied (Henseler, Ringle, \& Sarstedt, 2015). Variance Inflation Factor (VIF) for all constructs was less than 0.5 that showed no multicollinearity (Garson, 2016) between the constructs. The model fit condition was satisfied as SRMR was $0.072(<0.08)$ (Hock \& Ringle, 2006).

Table 3. Composite Reliability and Cronbach's Alpha

\begin{tabular}{ccc}
\hline Variable & Cronbach's Alpha & Composite Reliability \\
\hline INN & 0.923 & 0.936 \\
\hline OP & 0.918 & 0.936 \\
\hline IC & 0.849 & 0.898 \\
\hline TL & 0.885 & 0.916 \\
\hline KM & 0.889 & 0.912 \\
\hline LO & 0.882 & 0.914 \\
\hline
\end{tabular}

Next, figure 1 presents the measurement model. It shows that learning orientation, transformational leadership, knowledge management, and innovative culture are independent variables. Innovation is the mediating variable, while organization performance is the dependent variable. The final items loaded onto their respective constructs are shown in rectangular boxes. The loadings reaffirm findings of Table 2 that as they are all greater than 0.7, so they confirm convergent validity. The numbers on the arrows from IVs to DVs are direct path coefficients. As they are all positive, so they show a positive nature of the effect.

Figure 1. Measurement Model

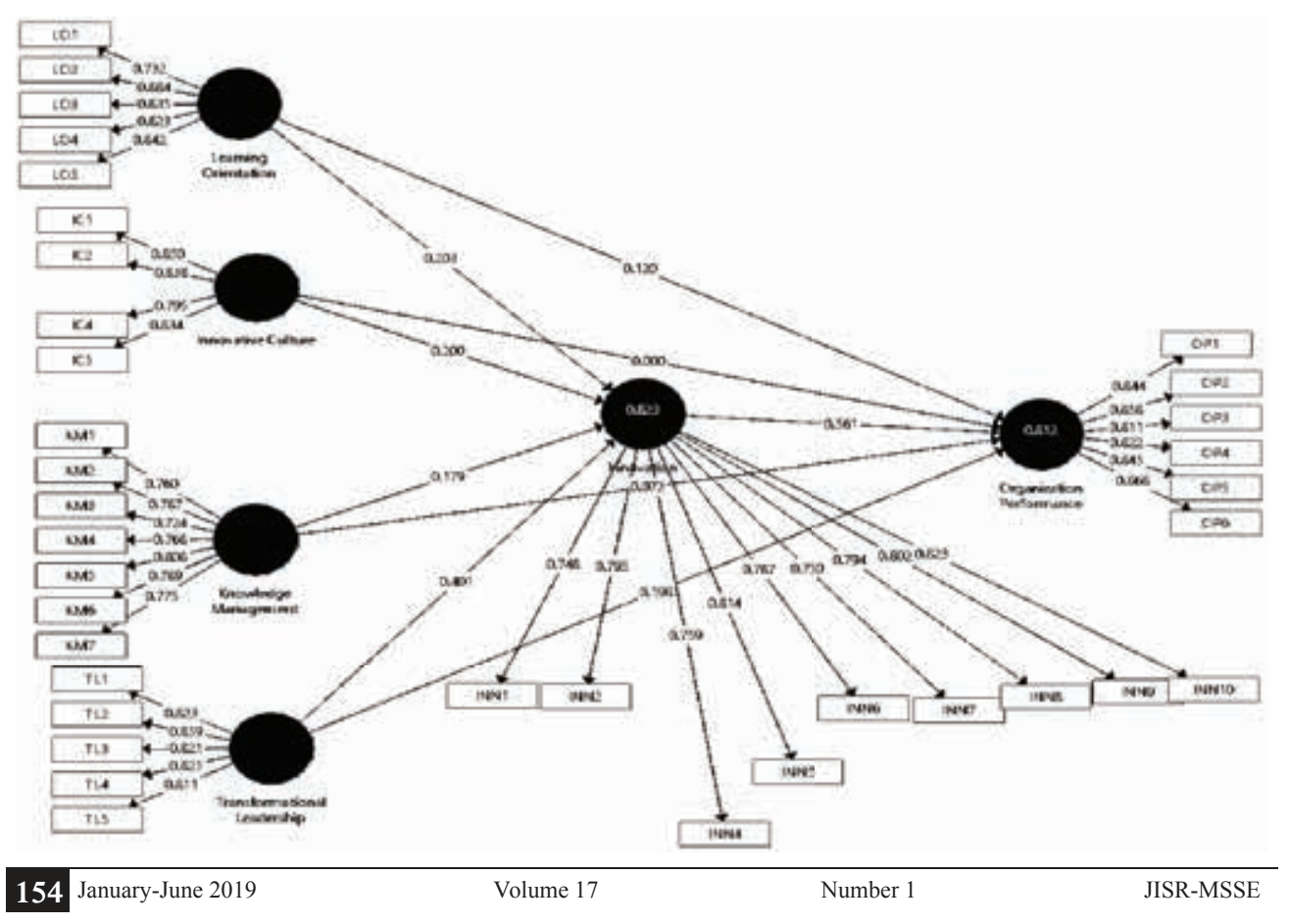


Table 4 represents hypotheses test results. Initially, relationships were studied using the PLS algorithm and later bootstrapping was run using 1000 subsamples to reveal significance between the variables. For mediator analysis, the direct and indirect effects were studied using Preacher and Hayes method (2008). The detail and discussion of the results are given below.

Table 4. Composite Reliability and Cronbach's Alpha

\begin{tabular}{|c|c|c|c|c|c|c|c|}
\hline \multirow[t]{2}{*}{ Impact } & \multirow[t]{2}{*}{$\begin{array}{l}\text { Path } \\
\text { Coefficient } \\
\text { (Direct) }\end{array}$} & \multicolumn{2}{|c|}{ Direct Effect } & \multicolumn{2}{|c|}{ Indirect Effect } & \multicolumn{2}{|c|}{$\begin{array}{l}\text { Biased } \\
\text { Corrected } \\
\text { Confidence } \\
\text { Interval } \\
\end{array}$} \\
\hline & & $t$-value & p-value & $t$-value & p-value & $2.5 \%$ & $97.5 \%$ \\
\hline $\mathrm{INN} \rightarrow \mathrm{OP}$ & 0.561 & 5.332 & 0.000 & & & 0.349 & 0.760 \\
\hline $\mathrm{IC} \rightarrow \mathrm{OP}$ & 0.000 & 0.003 & 0.998 & 2.379 & 0.018 & -.103 & 0.325 \\
\hline $\mathrm{IC} \rightarrow \mathrm{INN}$ & 0.200 & 2.468 & 0.014 & & & 0.054 & 0.359 \\
\hline $\mathrm{TL} \longrightarrow \mathrm{OP}$ & 0.198 & 1.994 & 0.046 & 3.470 & 0.001 & 0.250 & 0.607 \\
\hline $\mathrm{TL} \rightarrow \mathrm{INN}$ & 0.401 & 4.573 & 0.000 & & & 0.225 & 0.573 \\
\hline $\mathrm{KM} \rightarrow \mathrm{OP}$ & 0.072 & 1.122 & 0.262 & 2.539 & 0.011 & 0.053 & 0.329 \\
\hline $\mathrm{KM} \rightarrow \mathrm{INN}$ & 0.179 & 3.084 & 0.002 & & & 0.072 & 0.302 \\
\hline $\mathrm{LO} \rightarrow \mathrm{OP}$ & 0.120 & 1.173 & 0.241 & 2.018 & 0.044 & 0.005 & 0.425 \\
\hline $\mathrm{LO} \rightarrow \mathrm{INN}$ & 0.203 & 2.334 & 0.020 & & & 0.019 & 0.376 \\
\hline
\end{tabular}

\section{Innovation as a mediator between the innovative culture and performance}

Consult table 4. Findings indicate that p-value of the innovative culture's direct impact on organization performance is 0.998 whereas, $\mathrm{t}$-value $=0.003$. But for indirect impact, the p-value is 0.018 , and t-value is 2.379 . Therefore, the results suggest that between the innovative culture and performance, innovation acts as a full mediator. This results in accepting Hypothesis H1. All concerned path coefficients are also positive which indicate positive nature of relationships. However, caution must be applied in this result as $2.5 \%$ confidence interval is marginally negative. Thus, future researchers could study this relationship in other contexts to explore it further.

\section{Innovation as a mediator between transformational leadership and organization performance}

Table 4 shows that p-value for transformational leadership's direct impact on performance is 0.046 , whereas t-value $=1.994$. But for indirect impact, the p-value is 0.001 and $\mathrm{t}$-value is 3.470. These results show an insignificant direct effect of transformational leadership on performance, while a significant indirect effect and lead to the conclusion that innovation plays the role of a full mediator variable for this relationship. This results in accepting Hypothesis H2. Table 4.3 also includes statistics regarding bias-corrected confidence intervals. The lower limit of the confidence interval for transformational leadership and performance relationship is 0.250 while the upper limit is 0.607 . The other concerned confidence intervals also have satisfactory statistics and all concerned coefficients are also positive that indicate the positive type of relationships.

\section{Innovation as a mediator for the knowledge management and performance relationship}

Table 4 shows that for the direct impact of knowledge management on organization performance, the $\mathrm{p}$-value is 0.262 and $\mathrm{t}$-value is 1.122 . But the $\mathrm{p}$-value is 0.011 and $\mathrm{t}$-value is 2.539 for the indirect effect of KM on OP. These results show knowledge management's

\begin{tabular}{llll}
\hline JISR-MSSE & Volume 17 & Number 1 & January-June 2019 155
\end{tabular}


insignificant direct effect on performance whereas a significant indirect effect. This concludes that between knowledge management and organization performance, innovation acts as a full mediator. Hence, Hypothesis H3 is accepted. Table 4 also indicates that the concerned statistics for confidence intervals are also satisfactory. The path coefficients for effect of knowledge management on performance (0.072), the effect of knowledge management on innovation (0.179), and for effect of innovation on performance $(0.561)$ are all positive that show the positive type of relationship.

\section{Innovation as mediator between learning orientation and organization performance}

Finally, table 4 shows that for the direct impact of learning orientation on organization performance, the p-value 0.241 and t-value is 1.173 . But the p-value is 0.044 and t-value is 2.018 for the indirect effect of LO on OP. Hence, the results conclude that between learning orientation and organization performance, innovation acts as a full mediator. Hence, $\mathrm{H} 4$ is also accepted. All concerned confidence interval limits are satisfactory and all concerned coefficients have positive values as well.

\section{DISCUSSIONS}

\section{Innovation as a mediator between the innovative culture and performance}

For Pakistan based SMEs, this research provides a genuine contribution and understanding of the phenomena. It highlights how certain factors contribute to innovation and SMEs performance. Firstly, the results support H1 about innovation's mediating role in the relationship between innovative culture and performance. Certain past researchers also supported this role (Hogan \& Coote, 2014; Salman, Arshad, \& Bakar, 2016; Subhan, Mehmood, \& Sattar, 2013). Innovative culture could successfully bring innovation which would result in superior performance (Kostis et al., 2018; Rajapathirana \& Hui, 2018; Subhan et al., 2013). This research strengthens resource-based view (Amit \& Schoemaker, 1993), which asserts that companies which make better utilization of their knowledge and culture as a resource possess the capability to attain higher levels of innovation and produce better results.

The results support that innovative culture significantly affects SMEs performance. Innovative culture enhances the capability of SMEs to innovative that finally leads to the superior performance of SMEs (Halim et al., 2015). The results also support the positive effect of innovative culture on innovation. Innovative culture serves as the source of introducing innovative offerings. Certain other researchers also supported the positive effect of innovative culture on firm innovation (Filipescu, 2007; Naranjo-Valencia, 2010). The results also indicate that innovation positively impacts SMEs performance. Numerous past researches also indicate the positive effect of innovation on performance (Damanpour \& Evan, 1984; Wheelright \& Clark, 1992). Subramanian and Nilakanta (1996) suggest that innovative SMEs produce innovative products and services more quickly, thus cause an increase in sales and performance. Hence, SMEs in emerging countries like Pakistan should create an innovative culture in order to bring innovation in their services and products for meeting changing needs that could lead to superior performance. 


\section{Innovation as a mediator between the transformational leadership and performance}

Findings lead towards accepting H2 about innovation's mediating role for the relationship between transformational leadership and performance. This study strengthens transformational leadership theory (Burns, 1978), according to which managers using transformational leadership style have the ability to motivate employees through charismatic speech and intellectual stimulation for developing innovative thinking among employees that could help them in demonstrating better performance. Researchers have thus, highlighted the positive impact of transformational leadership on performance (Bass, 1985; Bass \& Avolio, 1995; Gardner \& Stough, 2002) and numerous scholars have supported intervening role of innovation between transformational leadership and firm performance (Jung, 2001; Robbins \& Coulter, 2005; Yang, 2008).

Similarly, scholars argue that transformational leaders boost the confidence of employees through charismatic speech and intellectual stimulation for involving them in innovative activities and motivate them for hard work (Akbari et al., 2017; Matzler, Schwarz, Deutinger, \& Harms, 2008). Transformational leaders work for instilling creativity and innovation in the organization. Arham's study (2014) on Malaysian SMEs reported that transformational leadership style was related to innovation. Other researchers have also supported the positive impact of transformational leadership on innovation (Bass \& Avolio, 1995; Denning, 2005; Gardner \& Stough, 2002).

\section{Innovation as a mediator between The knowledge management and performance}

Next, findings also lead towards accepting H3 contributing and supporting RBV which assets that enterprises which are better in managing their knowledge flow could become successful in enhancing innovative capability and achieve a high level of performance. Certain past researchers also revealed similar results (Gloet \& Terziovski, 2004; Wong \& Aspinwall, 2005).

Several pieces of research have argued about the positive influence of knowledge management on performance (Baddi \& Sharif, 2003; Liu \& Abdalla, 2013). Duhon (1998) argued that knowledge management was much necessary condition for achieving sustainable competitive advantage and superior performance in organizations. Similarly, knowledge management ensures proper flow of knowledge and upgrades organizational tendency for innovation (Quintas, 2002). Therefore, several past researchers have highlighted the positive impact of knowledge management on innovation (Cavusgil et al., 2003; Edvardsson, 2009).

\section{Innovation as a mediator between the learning orientation and performance}

Finally, findings lead to accepting H4. Thus, this study strengthens the theory of the growth of firms and highlights that learning-oriented SMEs can achieve high levels of innovation that could lead to higher performance. Empirical research recently conducted by Serna, Martínez, and Martínez (2016) for Mexican SMEs reported that the relationship between learning orientation and performance was positively mediated by innovation. Others also supported this mediating role by reporting similar findings in the context of SMEs (Baker \& Sinkula, 1999, 2009).

The results reveal learning orientation's positive impact on SMEs performance. Thus, this study highlights DCP according to which organizations should be learning oriented for

\begin{tabular}{llll}
\hline JISR-MSSE & Volume 17 & Number 1 & January-June 2019 \\
\hline
\end{tabular}


attaining better performance. An empirical research by Liao et al. (2012) on banking and insurance companies in Taiwan concluded that learning orientation was significantly related to the performance of SMEs. Furthermore, scholars suggest that learning-oriented SMEs adopt innovative procedures for improving quality of work, operational efficiency and innovative ideas and address competitive issues in a better way in contrast to those that are not learning oriented (Liao et al., 2012).

This study suggests SMEs working in Pakistan to focus on developing and using a transformational style in their firms and develop learning orientated culture. Further, it recommends those SMEs to use knowledge management systems and develop an innovative culture in their organizations so that their organizations could attain high performance through innovation. As SMEs are relatively small size setups compared to large public limited companies, therefore, it is normally easier to share knowledge and promote learning in the culture. Further, it feels more practical to share ideas and develop an innovative culture in SMEs because of low staff levels. Exercising transformational leadership might too feel easy because of lower level cultural complexities and politics.

\section{LIMITATIONS AND FUTURE RESEARCH}

One of the limitations of this research is that it was conducted only in Southern Punjab region of Pakistan. So researchers can conduct research in other regions of Pakistan also to enrich the findings. Another limitation is that this study could end up studying SMEs operating in certain sectors. So, future research could consider other SMEs like visa operators, educational institutions, chemical industries, transport companies, etc. This would help in generalizing the findings across further sectors. Moreover, this research studied innovation construct as a unidimensional variable, and therefore, further research can study mediating effect of the different aspect of innovation (e.g. product innovation, process innovation) between various variables pertaining to SMEs. Future research could also study SMEs with respect to their competitive advantage and business strategies as well.

\section{REFERENCES}

Abouzeedan, A. (2011). SME performance and its relationship to innovation. (Ph.D. thesis) Linköpings Universitet, Sweden.

Al-Husseini, S., \& Elbeltagi, I. (2016). Transformational leadership and innovation: A comparison study between Iraq's public and private higher education. Studies in Higher Education, 41(1), 159-181. doi: 10.1080/03075079.2014.927848.

Amit, R., Schoemaker, P. (1993). Strategic assets and organizational rent. Strategic Management Journal, 14(1), 33-46. doi: 10.1002/smj.4250140105

Akbari, M.H., Younesi, G., \& Zohoori, M. (2017). Relationship between transformational leadership and innovation. International Journal of Science and Engineering Applications, 6(8). doi;10.7753/IJSEA0608.1002

Arham, F.A. (2014). Leadership and performance: The case of Malaysian SMEs in the services sector. International Journal of Asian Social Science, 4(3), 343-355.

Baddi, A., Sharif, A. (2003). Information management and knowledge integration for enterprise innovation. Logistics Information Management, 16(2), 145-55. doi: $10.1108 / 09576050310467287$ 
Baker, W.E., \& Sinkula, J.M. (1999). The synergistic effect of market orientation and learning orientation on organizational performance. Journal of Academy of Marketing Science, 27(4), 411-427. doi: 10.1177/0092070399

Baker, W.E., \& Sinkula, J.M. (2009). The complementary effects of market orientation and entrepreneurial orientation on profitability in small businesses. Journal of Small Business Management 47(4), 443-464. doi: 10.1111/j.1540-627X.2009.00278.x

Bass, B.M. (1985). Leadership and performance beyond expectations. NY: The Free Press.

Bass, B.M., \& Avolio, B.J. (1995). MLQ, multifactor leadership questionnaire (2nd edition). CA: Mind Garden.

Bessant, J., \& Tidd, J. (2007). Innovation and entrepreneurship. UK: Wiley.

Burns, J.M. (1978). Leadership. NY: Harper \& Row.

Calantone, R.J., Cavusgil, S.T., \& Zhao, Y. (2002). Learning orientation, firm innovation capability, and firm performance. Industrial Marketing Management, 31(6), 515-524. doi: 10.1016/S0019-8501(01)00203-6

Carrillat, F.A., Jaramillo, F., \& Locander, W.B. (2004). Market-driving organizations: A framework. Academy of Marketing Science Review, 5, 1-14.

Cavusgil, S.T., Calantone, R.J., \& Zhao, Y. (2003). Tacit knowledge transfer and firm innovative capability. Journal of Business \& Industrial Marketing, 18(1), 6-21. doi: $10.1108 / 08858620310458615$

Damanpour, F., \& Evan, W.M. (1984). Organizational innovation and performance: The problem of organizational lag. Administrative Science Quarterly, 29(3), 392-409. doi: $10.2307 / 2393031$

Daskalakis, S., \& Mantas, J. (2008). Evaluating the impact of a service-oriented framework for healthcare interoperability. Studies in Health Technology and Informatics, 136, 285-290.

Denning, S. (2005). Transformational innovation: A journey by narrative. Strategy \& Leadership, 33(3), 11-16. doi: 10.1108/10878570510700119

Duhon, B. (1998). It's all in our heads. Inform, 12(8), 8-13.

Edvardsson, I.R. (2009). Is knowledge management losing ground? Developments among Icelandic SMEs. Knowledge Management Research \& Practice, 7(1), 91-9. doi: $10.1057 / \mathrm{kmrp} .2008 .30$

Elkins, T., Keller, R.T. (2003). Leadership in research and development organizations: A literature review and conceptual framework. The Leadership Quarterly, 14, 587-606. doi: 10.1016/S1048-9843(03)00053-5

Felício, J.A., Couto, E., \& Caiado, J. (2014). Human capital, social capital and organizational performance. Management Decision, 52(2), 350-364. doi: 10.1108/MD-04-2013-0260

Filipescu, D-A. (2007). Innovation and internationalization. A focus on the Spanish exporting firms. Universidad Autonoma de Barcelona.

Gallagher, S. (2008). A strong organization culture drives organizational performance and success. Employment Relations Today, 35(1), 25-31. doi: 10.1002/ert.20185

Gardner, L., \& Stough, C. (2002). Examining the relationship between leadership and emotional intelligence in senior level managers. Leadership and Organization Development Journal, 23(1-2), 68-78. doi: 10.1108/01437730210419198

Garson, G. D. (2016). Partial least squares: Regression \& structural equation models. USA: Statistical Publishing Associates.

Gault, F. (2018). Defining and measuring innovation in all sectors of economy. Research Policy, 47(3), 617-622. 
Ghosh, B., Liang, T.W., Meng, T.T., \& Chan, B. (2001). The key success factors, distinctive capabilities, and strategic thrusts of top SMEs in Singapore. Journal of Business Research, 51(3), 209-221. doi: 10.1016/S0148-2963(99)00047-8

Gloet, M., \& Terziovski, M. (2004). Exploring the relationship between knowledge management practices and innovation performance. Journal of Manufacturing Technology Management, 15(5), 402-9. doi: 10.1108/17410380410540390

Gonzalez, R.V.D., \& Martins, M.F. (2017). Knowledge management process: A theoretical-conceptual research. Gestão \& Produção, 24(2), 248-265. doi: 10.1590/0104-530X0893-15

Halim, H. A., Ahmad, N. H., Ramayah, T., Hanifah, H., Taghizadeh, S. K., \& Mohamad, M. N. (2015). Towards an innovation culture: Enhancing innovative performance of Malaysian SMEs. Academic Journal of Interdisciplinary Studies, 4(2), 85. doi: 10.5901/ajis.2015.v4n2p85

Hanaysha, J.R.M., Khalid, K., Nik Mat, N.K., Sarassina, F., Bin Ab Rahman, M.Y., \& Bin Zakaria, A.S. (2012). Transformational leadership and job satisfaction. American Journal of Economics, Special Issue, 145-148. doi: 10.5923/j.economics.20120001.32

Hartmann, A. (2006). The role of organizational culture in motivating innovative work behavior in construction organizations. Construction Innovation, 6(3), 159-172. doi: $10.1108 / 14714170610710712$

Henseler, J., Ringle, C.M., \& Sarstedt, M. (2012). Using partial least squares path modeling in international advertising research: Basic concepts and recent issues. In S. Okzaki (ed.), Handbook of partial least squares: Concepts, methods, and applications in marketing and related fields (pp. 252-276). Berlin: Springer.

Henseler, J., Ringle, C.M., \& Sarstedt, M. (2015). A new criterion for assessing discriminant validity in variance-based structural equation modeling. Journal of the Academy of Marketing Science, 43(1), 115-135. doi: 10.1007/s11747-014-0403-8

Höck, M., \& Ringle, C.M. (2006). Strategic networks in the software industry: An empirical analysis of the value continuum. IFSAM 8th World Congress, Berlin. Retrieved from http://www.ibl-unihh.de/IFSAM06.pdf.

Hogan, S.J., Coote, L.V . (2014). Organizational culture, innovation, and performance: A test of Schein's model. Journal of Business Research, 67(8), 1609-1621. doi: 10.1016/j.jbusres.2013.09.007

Hung, R.Y.Y., Lien, B.Y.H., Fang, S.C., \& McLean, G.N. (2010). Knowledge as a facilitator for enhancing innovation performance through total quality management. Total Quality Management and Business Excellence, 21(4), 425-438. doi:10.1080/14783361003606795

Hurley, R.F., \& Hult, G.T. (1998). Innovativeness, market orientation, and organizational learning: An integration and empirical examination. Journal of Marketing, 62(3), 42-54. doi: $10.2307 / 1251742$

Hussain, J., Shah, F.A., Rehman, W., \& Khan, Y. (2018). Learning orientation and performance: The interaction effect of entrepreneurial orientation. Pakistan Business Review, 19(4), 960-977.

Jabeen, R., Alekam, J.M.E., Aldaoud, K.A.M., Mat, N.K.N., Zureigat, B.N.I., Nahi, A.K., \& al Junaidi, A.M.F. (2013). Antecedents of firm's performance. Empirical evidence from Yemeni SME's. American Journal of Economics, 3(1), 18-22. doi: 10.5923/j.economics.20130301.04 
Jung, D. (2001). Transformational and transactional leadership and their effects on creativity in groups. Creativity Research Journal, 13, 185-95. doi: 10.1207/S15326934CRJ1302_6

Jung, D.I., Sosik, J. (2002). Transformational leadership in work groups: The role of empowerment, cohesiveness and collective efficacy on perceived group performance. Small Group Research, 33, 313-36. doi: 10.1177/10496402033003002

Kaufmann, A., \& Tödtling, F. (2001). Science-industry interaction in the process of innovation: The importance of boundary-crossing between systems. Research Policy, 30(5), 791-804. doi: 10.1016/S0048-7333(00)00118-9

Kharabsheh, R., Ensour, W., \& Bogolybov, P. (2017). Learning orientation, market orientation and organizational performance: The mediating effect of absorptive capacity. Business and Economic Research, 7(1), 114-127. doi :10.5296/ber.v7i1.10294

Kneipp, J.M., Gomes, C.M., Bichueti, R.S., Frizzo, K., \& Perlin, A.P. (2019). Sustainable innovation practices and their relationship with the performance of industrial companies. Revista de Gestão, 26(2), 94-111. doi: 10.1108/REGE-01-2018-0005

Kostis, P.C., Kafka, K.I., \& Petrakis, P.E. (2018). Cultural change and innovation performance. Journal of Business Research, 88, 306-313.

Kumarasinghe, P. (2018). Open innovation strategy and performance of SME in Sri Lanka. International Journal of Business and Management Invention (IJBMI), 7(3), 38-44.

Lioa, S.H., Chang, W.J., Hu, D.C., \& Yueh, Y.L. (2012). Relations among organizational culture, knowledge acquisition, organizational culture, knowledge acquisition, organizational learning, and organizational innovation in Taiwan's making and insurance industries. The international Journal of Human Resource Management, 23(1), 52-70. doi: 10.1080/09585192.2011.599947

Liu, Y., Abdalla, A.N. (2013). Evaluating the managerial behavior of managing knowledge in Chinese SMEs. Information Technology and Management Journal, 14(2), 159-165. doi: 10.1007/s10799-013-0157-X

Manzoor, F., Wei, L., Nurunnabi, M., Subhan, Q.A., Shah, S.I.A., \& Fallatah, S. (2019). The impact of transformational leadership on job performance and CSR as mediator in SMEs. Sustainability, 11(2), 436. doi:10.3390/su11020436.

Martins, E., \& Terblanche, F. (2003). Building organizational culture that stimulates creativity and innovation. European Journal of Innovation Management, 6(1), 64-74. doi: $10.1108 / 14601060310456337$

Matzler, K., Schwarz, E., Deutinger, N. \& Harms, R. (2008). Relationship between transformational leadership, product innovation, and performance in SMEs. Journal of Small Business and Entrepreneurship, 21(2), 139-152. doi: $10.1080 / 08276331.2008 .10593418$

Mclean, L. (2005). Organizational culture's influence on creativity and innovation: A review of the literature and implications for human resource development. Advances in Developing Human Resources, 7(2), 226-46. doi: 10.1177/1523422305274528

Mehmood, K. K., Sonia, F., \& Umar, A. (2016). Impact of organic structure on competitive performance of pharmaceutical companies in Pakistan: Study of mediating roles. Pakistan Journal of Social Sciences, 36(2), 821-834.

Miron, E., Erez, M., \& Naveh, E. (2004). Do personal characteristics and cultural values that promote innovation, quality, and efficiency compete or complement each other? Journal of Organizational Behavior, 25(2), 175-199. doi: 10.1002/job.237

Naranjo-Valencia, J. (2010). La cultura organizacional como determinante de la innovación de producto (Un estudio empírico (Tesis doctoral inédita)). Espana: Universidad de Murcia.

\begin{tabular}{llll}
\hline JISR-MSSE & Volume 17 & Number 1 & January-June 2019 \\
\hline
\end{tabular}


Nunes, M.B., Annansingh, F., \& Eaglestone, B. (2006). Knowledge management issues in knowledge-intensive SMEs. Journal of Documentation, 62(1), 101-119. doi: $10.1108 / 00220410610642075$

Nunnaly, J. (1978). Psychometric theory. USA: McGraw-Hill.

Oncioiu, I. (2013). Business innovation, development, and advancement in the digital economy. PA: IGI Global.

Parlby, D., \& Taylor, R. (2000). The power of knowledge: A business guide to knowledge Management. Available at: www.kpmgconsulting.com/index.html.

Penrose, E.T. (1959). The theory of the growth of the firm. NY: Oxford University Press.

Podsakoff, P.M., MacKenzie, S.B., \& Bommer, W.H. (1996). Transformational leader behaviours and substitutes for leadership as determinants of employee satisfaction, commitment, trust, and organizational citizenship behaviours. Journal of Management, 22(2), 259-298. doi: 10.1177/014920639602200204

Preacher, K.J., Hayes, A.F. (2008). Asymptotic and resampling strategies for assessing and comparing indirect effects in multiple mediator models. Behavior Research Methods, 40, 879-891. doi: 10.3758/BRM.40.3.879

Quintas, P. (2002). Managing knowledge in a new century. In Little, S., Quintas, P., \& Ray, T. (Eds.), Managing Knowledge: An Essential Reader (pp. 1-14). London: The Open University of Sage Publications.

Rajapathirana, R.P.J., \& Hui, Y. (2018). Relationship between innovation capability, innovation type, and firm performance. Journal of Innovation and Knowledge, 3(1), 44-55.

Rasula, J., Vuksic, V.B., \& Stemberger, M.I. (2012). The impact of knowledge management on organizational performance. Economic and Business Review, 14(2), 147-168.

Ricardo, R., \& Wade, D. (2001). Corporate performance management: How to build a better organization through measurement driven strategies alignment. UK: Butterworth Heinemann.

Robbins, S.P. \& Coulter, M. (2005). Management (8th edition). NJ: Prentice Hall.

Salman, R., Arshad, D., \& Bakar, L.J.A. (2016). Enhancing SMEs performance through innovative cultural values in Pakistan. International Business Management, 10(16), 3673-3681. doi: 10.3923/ibm.2016.3673.3681

Seaver, D.S. (2010). Effect of transformational leadership in a cross-cultural organization: A case study. (Ph.D. Dissertation). Capella University, United States.

Serna, M.D.C.M., Martínez, J.E.V., \& Martínez, J.V. (2016). The impact of learning orientation on innovation and performance in SME'S in Mexico. International Review of Management and Business Research, 5(1), 48-64.

Sheng, M.L., Chien, I. (2016). Rethinking organizational learning orientation on radical and incremental innovation in high-tech firms. Journal of Business Research, 69, 2302-2308.doi: 10.1016/j.jbusres.2015.12.046

Skerlavaj, M., Song, J.H., \& Lee, Y. (2010). Organizational learning culture, innovative culture, and innovations in South Korean firms. Expert Systems with applications, 37(9), 6390-6403. doi: 10.1016/j.eswa.2010.02.080

Skilbeck, R. (2017). Driving a culture of innovation: Insights from PageUp's Global HR innovation study. Australia: PageUp People Limited. 
Subhan, Q.A., Mehmood, M.R., \& Sattar, A. (2013, January). Innovation in small and medium enterprises (SME's) and its impact on economic development in Pakistan. In Proceedings of the 6th International Business and Social Sciences Research Conference (pp. 3-4), Dubai.

Subramanian A., \& Nilakanta, S. (1996). Organisational innovativeness: Exploring the relationship between organisational determinants of innovation, types of innovations, and measures of organisational performance. Omega, 24(6), 631-647. doi: 10.1016/S0305-0483(96)00031-X

Tajasom, A., Hung, D.K.M., Nikbin, D., \& Hyun, S.S. (2015). The role of transformational leadership in innovation performance of Malaysian SMEs. Asian Journal of Technology Innovation, 23(2), 172-188. doi: 10.1080/19761597.2015.1074513

Teece, D.J., Pisano, G., \& Shuen, A. (1997). Dynamic capabilities and strategic management. Strategic Management Journal, 18(7), 509-533. doi: 10.1002/(SICI)1097-0266(199708)

Tidd, J. (2001). Innovation management in context: Environment, organization and performance. International Journal of Management Reviews, 3(3), 169-183. doi: $10.1111 / 1468-2370.00062$

Tidd, J., Bessant, J., \& Pavitt, K. (2002). Managing innovation: Integrating technological, market and organizational change (2nd edition). UK: Wiley.

Turulja, L., \& Bajgoric, N. (2019). Innovation, firms' performance and environmental turbulence: Is there a moderator or mediator? European Journal of Innovation Management, 22(1), 213-232, doi: 10.1108/EJIM-03-2018-0064

Waheed, A., Miao, X., Waheed, S., Ahmad, N., \& Majeed, A. (2019). How new HRM practices, organizational innovation, and innovative climate affect the innovation performance in the IT industry: A moderated-mediation analysis. Sustainability, 11(3), 621. doi:10.3390/su11030621

Wang, D.S. (2019). Association between technological innovation and firm performance in small and medium-sized enterprises: The moderating effect of environmental factors. International Journal of Innovation Science, 11(2), 227-240, doi:10.1108/IJIS-04-2018-0049

Wong, K.Y., \& Aspinwall, E. (2005). An empirical study of the important factors for knowledge-management adoption in the SME sector. Journal of Knowledge Management, 9(3), 64-82. doi: 10.1108/13673270510602773

Yang, C.W. (2008). The relationships among leadership styles, entrepreneurial orientation, and business performance. Managing Global Transitions, 6(3), 257-275.

Zahra, S., Belardino, S., \& Boxx, W. (1988). Organizational innovation: Its correlates and its implications for financial performance. International Journal of Management, 5, 133-142. 


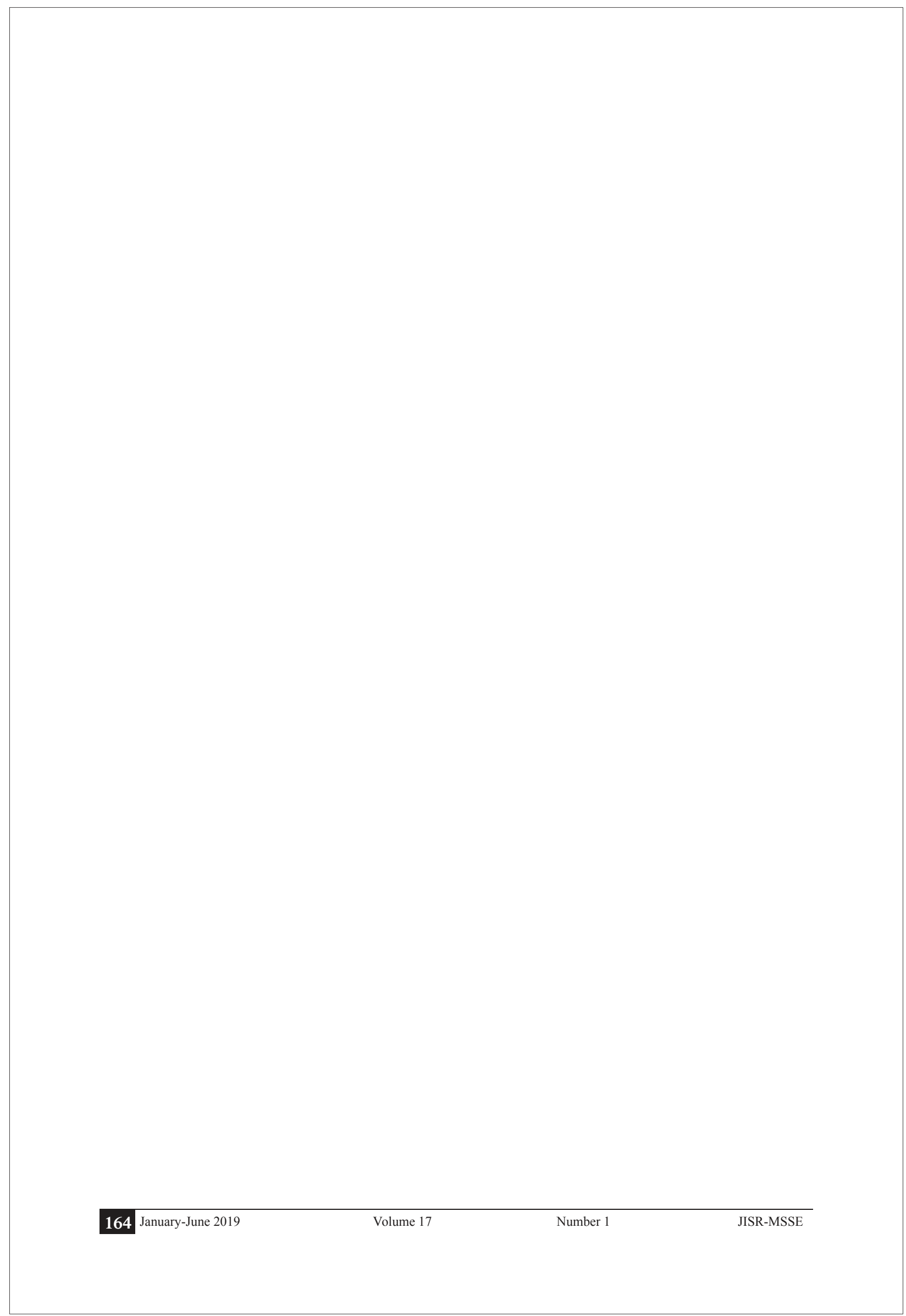

